DOI: 10.2478/v10014-008-0006-5

Agrovoc descriptors: valerianella locusta, leaves, weight, dry matter content, crop yield, varieties, planting equipment, cultivation, sowing

Agris category codes: F01, F62

COBISS Code 1.01

\title{
Corn salad (Valerianella olitoria L.) yield response to cell size of plug trays
}

\author{
Dragan ŽNIDARČIČํ ${ }^{1}$ Nina KACJAN-MARŠIĆ ${ }^{2}$
}

Received March 20, 2008; accepted April 28, 2008.

Delo je prispelo 20. marca 2008; sprejeto 28. aprila 2008.

\section{ABSTRACT}

The research was undertaken to determine if the plug tray cell size had an impact on plant characteristics and yield of corn salad (Valerianella olitoria L.). Seeds of four cultivars ('Ljubljanski', 'Holandski', 'Flavor' and 'Masse') were sown in styrofoam plug trays with 40 cells $\left(60 \mathrm{ml} \mathrm{cell}{ }^{-1}\right), 84$ cells $\left(35 \mathrm{ml} \mathrm{cell}^{-1}\right)$ and 160 cells $\left(20 \mathrm{ml} \mathrm{cell}^{-1}\right)$. Plants growth generally increased with cell size, though the effect varied with different cultivars. An increase in cell volume resulted in an increase in leaves height, leaves number and leaves fresh mass, as well as percentage of dry matter. Cv. 'Holandski' was obtained the highest leaves fresh mass regardless of cell volume.

Key words: Valerianella olitoria, corn salad, yield components, leaves fresh mass, percentage of dry matter

\section{IZVLEČEK}

\section{VPLIV VELIKOSTI CELICE GOJITVENE PLOŠČE NA PRIDELEK MOTOVILCA (Valerianella olitoria L.)}

Raziskava je bila izvedena z namenom ugotoviti, ali velikost celice gojitvene plošče lahko vpliva na lastnosti in pridelek motovilca (Valerianella olitoria L.). Seme štirih kultivarjev ('Ljubljanski', 'Holandski', 'Flavor' in 'Masse') je bilo posejano v stiroporne gojitvene plošče s 40 celicami (60 $\mathrm{ml} /$ celico), 84 celicami (35 ml/celico) in 160 celicami (20 ml/celico). Na splošno je bila rast rastlin intenzivnejša $z$ večanjem prostornine celice, medtem ko so se kultivarji različno odzivali na velikost celic. Večji volumen celice se je izrazil v večjih listih, večjem številu listov, večjem pridelku listne mase, prav tako pa tudi v večjem deležu suhe snovi. Cv. 'Holandski' je dal največji pridelek zelene listne mase ne glede na prostornino celic.

Ključne besede: Valerianella olitoria, motovilec, značilnosti pridelka, teža svežih listov, odstotek sušine

\footnotetext{
${ }^{1}$ M. Sc. Agr., Biotechnical Faculty, University of Ljubljana, SI-1111 Ljubljana, Jamnikarjeva 101; E-mail: dragan.znidarcic@bf.uni-lj.si

${ }^{2}$ Assistant Prof., Ph. D., ibid; E-mail: nina.kacjan.marsic@bf.uni-lj.si
} 


\section{INTRODUCTION}

Despite rich assortment of locally grown and imported vegetables in Slovenia supply of fresh and quality vegetables in winter months is poor. Such leafy vegetables as corn salad (Valerianella olitoria L.), which do not required high temperature and low light density, should be grown in this season of a year.

In the past vegetables were grown in greenhouse using ground beds or in outdoor ground beds. In last decades, the entire vegetable production system has received attention and changes because the necessity to improve yield and vegetable quality. Nowadays, growers have showed possibilities of vegetable production in alternative systems of production. One from possible system is also using various types of containers, primarily plug trays. With this system, each plant grows in an individual cell so there is less competition among plants and greater uniformity (NeSmith and Duval, 1998). Lee and Yang (1999) also reported that leafy lettuce, Chinese kale and water convolvulus produced from plug trays had a storage life even 3.6, and 2 days longer, respectively, than those grown in soil.

The number of plants in a tray depends on the cell size for each plant. Vegetables are commonly grown in plug trays with 30 to 300 cells (Walter et al., 2005). In general, larger cell leads to greater early yield and they are also easier to manage because the greater soil volume holds more water and nutrients. A trend among many commercial vegetable growers is toward more cells per tray (smaller cells), so that more plants can be grown in the limited space available (Vavrina, 1995). Plant responses to reduced soil volume have been reported for a wide range of crops with some conflicting data among them. There are differences in responses reported between species and even between cultivars within a species (Vavrina, 2001).

The effect of cell size and root restriction on leaf growth has been documented for tomato (Weston and Zandstra, 1986), bell peppers (Weston, 1998)), cabbage (Csizinsky and Shuster, 1993), squash (NeSmith, 1993), watermelon (Liu and Latimer, 1995), lettuce (Nicola and Cantliffe, 1996), salvia (van Iersel, 1997) and rocket (Šink, 2006). To our knowledge this is the first report describing the impact of plug tray cell volume on corn salad yield.

\section{MATERIAL AND METHODS}

The greenhouse experiment were conducted in the Experimental Field $\left(\begin{array}{ll}4 & 0 \\ & \end{array} 4^{\prime} \mathrm{N}, 14^{\circ} 31^{\prime} \mathrm{W}\right.$, $300 \mathrm{~m}$ above sea level) of the Biotechnical Faculty in Ljubljana, Slovenia. The experiment was designed as a factorial complete randomised block. In each of four blocks a combination of cultivar and three root cell volume (Tab. 1) was replicated three times. Each replication consisted of a single tray. There were cultivars of corn salad that are grown commercially for fresh market in Slovenia: 'Ljubljanski' (Semenarna), 'Holandski' (Semenarna), 'Masse' (Bejo) and 'Favor' (Enza Zaden). 
ŽNIDARČIČ, D. in sod.: Corn salad (Valerianella olitoria L.) yield response to cell size ..61

Table 1: Dimension of cell size used to grow corn salad

\begin{tabular}{|c|cccc|}
\hline $\begin{array}{c}\text { Plug tray } \\
\left(\text { cell } \mathrm{m}^{-2}\right)\end{array}$ & $\begin{array}{c}\text { Cell depth } \\
(\mathrm{mm})\end{array}$ & $\begin{array}{c}\text { Cell diameter } \\
(\mathrm{mm})\end{array}$ & $\begin{array}{c}\text { Cell volume } \\
(\mathrm{ml})\end{array}$ & $\begin{array}{c}\text { Cell No. } \\
\left(\mathrm{m}^{-2}\right)\end{array}$ \\
\hline 40 & 55 & 55 & 60 & 166 \\
84 & 40 & 40 & 35 & 350 \\
160 & 29 & 45 & 20 & 667 \\
\hline
\end{tabular}

Styrofoam trays were hand-filled with commercial peat-based growing medium Klasmann Tray substrate $\left(\mathrm{pH} 6-6.5 ; \mathrm{N} 180 \mathrm{mg} \mathrm{L}^{-1} ; \mathrm{P}_{2} \mathrm{O}_{5} 210 \mathrm{mg} \mathrm{L}^{-1} ; \mathrm{K}_{2} \mathrm{O} 250 \mathrm{mg} \mathrm{L}^{-1} ; \mathrm{MgO} 85 \mathrm{mg} \mathrm{L}^{-1}+\right.$ microelements). Two to three seeds were sown in each plug cell on February 12, 2008. Thinning was done at the second true leaf stage leaving one plant per cell. The trays were covered with a $10 \%$ shade cloth until seed germination was complete. About 2 weeks after sowing, the shade cloth was removed and plants were exposed to natural light conditions.

Greenhouse conditions and the practices used to produce the seedling were kept as near-ideal ideal as possible. Watering was done as needed (generally four times per week). Once weekly all the plants were supplied with a water-soluble fertilizer (Peters Professional 15-15-15, Scotts Company). In the compartment, average daily temperatures were $14 \pm 2{ }^{\circ} \mathrm{C}$. Ventilation temperature was set at $2{ }^{\circ} \mathrm{C}$ above the heating temperature set points. Relative humidity was maintained at $75 \pm 10 \%$ using ventilation throughout the growing season. Greenhouse climate was monitored and controlled by a DGT-Volmatic System.

Corn salads were extracted from trays on 26 March, cull or diseased plants were removed. Ten plants from each treatment were randomly sampled for harvesting and measuring plant height, number of leaves per plant and leaves fresh mass. The dry matter percentage of leaves tissue was determined by drying fresh leaves for $48-52 \mathrm{~h}$ at $60-64$.

The data are reported as mean values with a standard error (S.E.). The data were subjected to one-way or two-way analysis of variance and the differences among treatments were determined by Tukey's test $(P<0.05)$. Each treatment consisted of five replicate samples.

\section{RESULTS AND DISCUSSION}

As we expected, cell size had an even greater impact on the rate of crop development. The plants grown in the largest plug volume ( $90 \mathrm{ml}-40$ cells plug tray) were much higher and heavier (Fig. 2 and 3) than that grown in smaller volumes so the statistical analysis comparing average fresh leaves mass per plant, plant height (above-ground) and number of leaves per plant, between the cultivars was made separately for each size of plug volume.

When cultivars were compared by plant height (Fig. 1), statistically significant differences were found in all three plug volumes, but they are more expressed between cultivars grown in the largest plug volume $(90 \mathrm{ml})$ where cv. 'Holandski' had in average the highest plants $(89 \mathrm{~mm})$ and cv. 'Favor' the smallest $(56 \mathrm{~mm})$. Cv. 'Holandski' had the highest plants also when plants were grown in middle and small size plug volume (60 and $20 \mathrm{ml}$ ) and cv. 'Favor', grown in $60 \mathrm{ml}$ plug volume and cv. 'Ljubljanski', grown in $20 \mathrm{ml}$ had the smallest plants. According to Nicola and 
Cantliffe (1996), the reduced plant height was caused by the reduced water-holding and fertilizer capacity of the small medium volume.

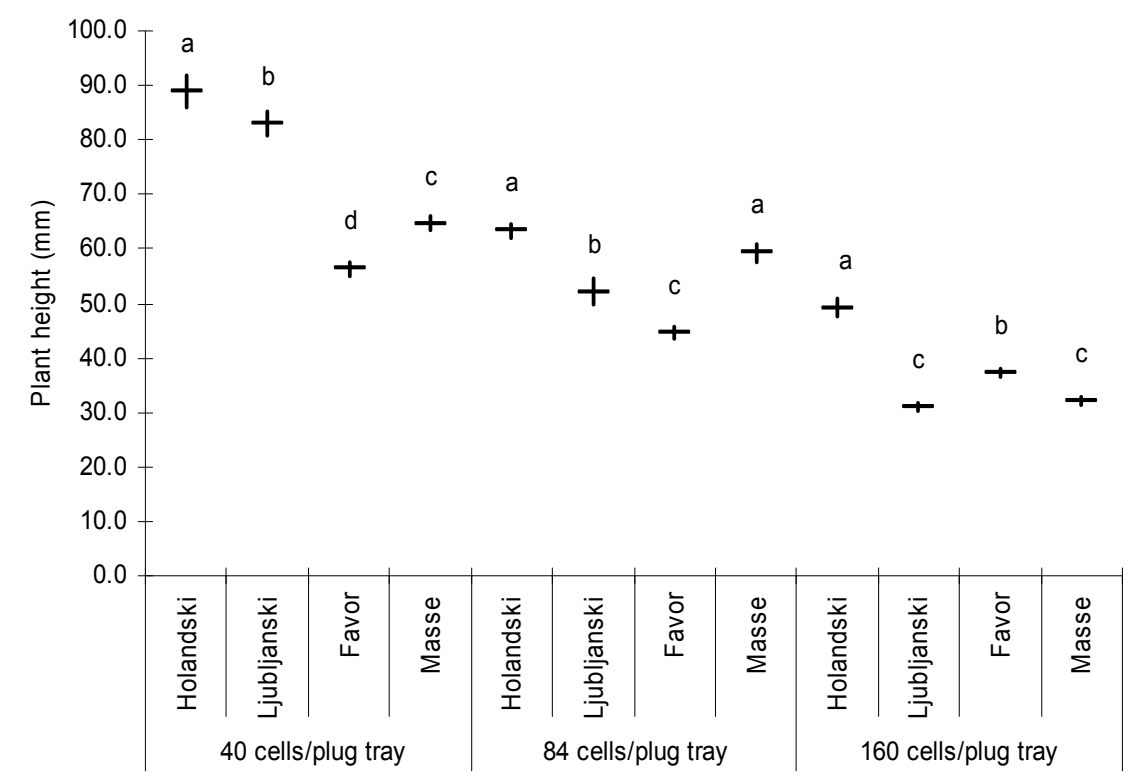

Figure 1: Influence of cell size on plants height $(\mathrm{mm})$. Vertical bars indicate standard errors.

The number of full expanded leaves often reflect the technological maturity of corn salad plants. Our result showed (Fig. 2) that a highest cell volume significant increased the number of leaves per plant. As plant population density increases, each plant produces fewer leaves per plant due to increased plant competition. However, under similar environmental conditions, the larger number of plants compensate with leaves yields per unit area similar to those in lower plant populations. In our research, it seems that the yield was affected mainly by number of leaves per plant.

When plant population density is low $\left(40\right.$ cells tray $\left.{ }^{-1}\right)$, there is little, between-plant competition. The individual plants will grow larger and produce more and higher leaves. The leaves number at highest cell size was in average $50.5 \%$ greater than those above smallest cell size. The plants grown in $90 \mathrm{ml}$ cell volume were the most developed and had in average from 7.5 (cv. 'Holandski') to 11.5 (cv. 'Favor') developed leaves per plants, those grown in $60 \mathrm{ml}$ cell volume had from 6 (cv. 'Masse') to 9 (cv. 'Holandski') expanded leaves per plant and grown in $20 \mathrm{ml}$ cell volume had only from 3.2 (cv. 'Masse') to 5.6 (cv. 'Favor') expanded leaves per plant. 


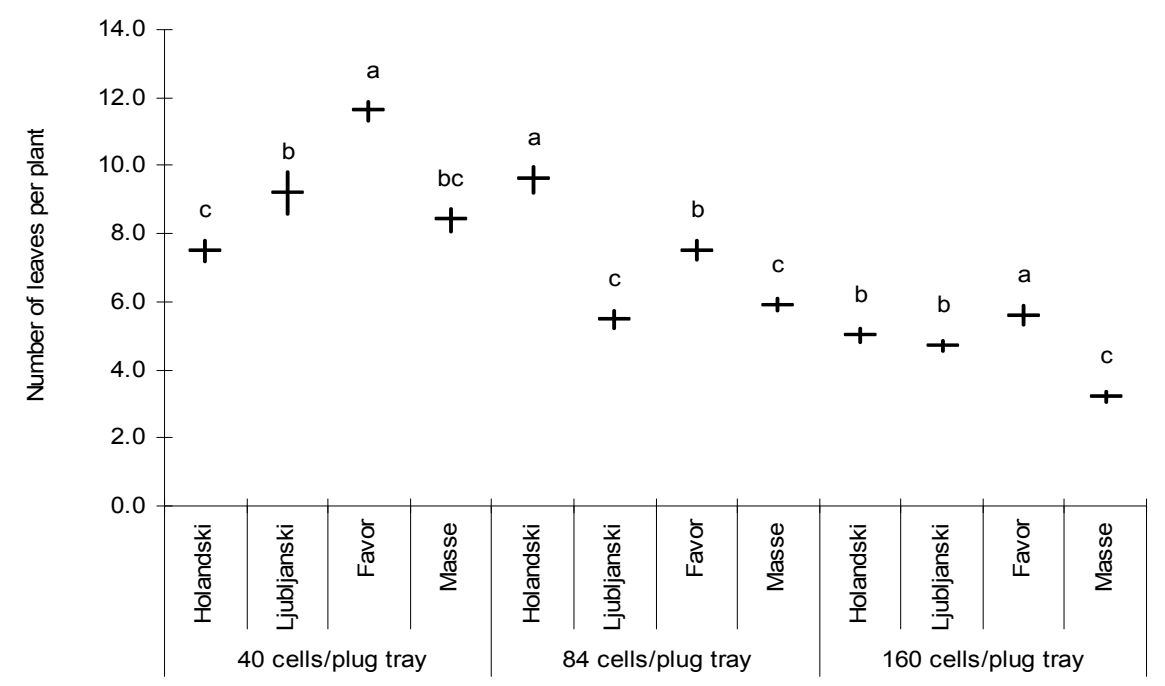

Figure 2: Influence of cell size on leaves number per plant. Vertical bars as in Fig. 1.

Statistical significant differences among cultivars were found in leaves fresh mass at all kinds of plug trays (Fig. 3). There were clear indications that cv. 'Holandski' was the dominant cultivar. In plug trays with 40 cells the results showed that in average the highest leaves fresh mass per plant were recorded by cv. 'Holandski' $(2,7 \mathrm{~g}$ plant $^{-1}$ ) and there were no significant differences in average leaves mass between other cultivars grown in the same cell volume. In plug trays with 84 cells, the highest mass per plant gave also the $\mathrm{cv}$. 'Holandski' $\left(1.56 \mathrm{~g} \mathrm{plant}^{-1}\right)$, and the lowest were recorded by 'Favor' ( $\left.0.75 \mathrm{~g} \mathrm{plant}^{-1}\right)$. The lowest mass per plant were recorded by plants grown in the smallest cell volume $\left(20 \mathrm{ml}-160\right.$ cell tray $\left.^{-1}\right)$, where the highest mass per plant were also recorded by cv. 'Holandski' $\left(0.7 \mathrm{~g} \mathrm{plant}^{-1}\right)$ and the lowest by cv. 'Ljubljanski' $\left(0.3 \mathrm{~g}\right.$ plant $\left.^{-1}\right)$. The differences in plant mass between cultivars were smaller, when plants were grown in the smallest cell volume $(20 \mathrm{ml})$ in comparison with those grown in 60 and $90 \mathrm{ml}$, respectively. In general, plants grown in $20 \mathrm{ml}$ cell had less leaves mass compared with plants grown in 35 and 60 cell volume. Because the plants in 20 cell volume received the same amount of fertilizer as the plants in the other cell volumes, they may have had more fertilizer stress.

Yield per plug tray is the product of leaves mass per plant and number of plants per unit area. Small cell size (higher densities) increased the number of plants per unit area, whereas at large cell size (lower densities) the plants number per unit area declined. In our research, the greater number of leaves per plant reflected in the greater yield per plug tray (data not shown). 


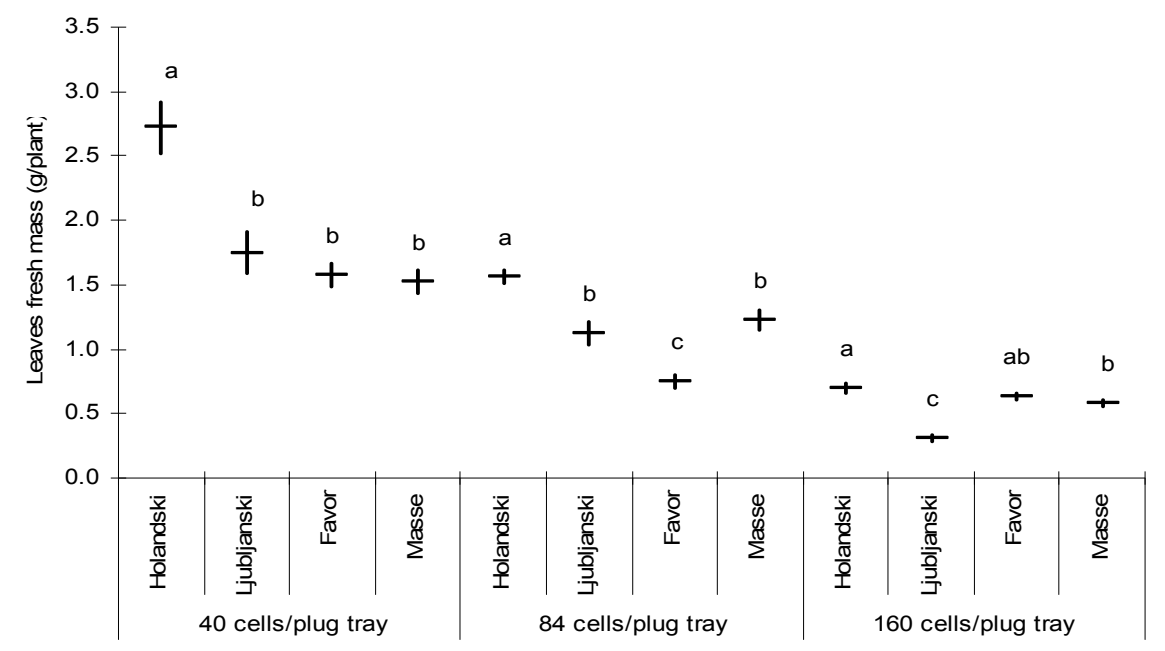

Figure 3: Influence of cell size on leaves fresh mass $\left(\mathrm{g}\right.$ plant $\left.{ }^{-1}\right)$. Vertical bars as in Fig. 1.

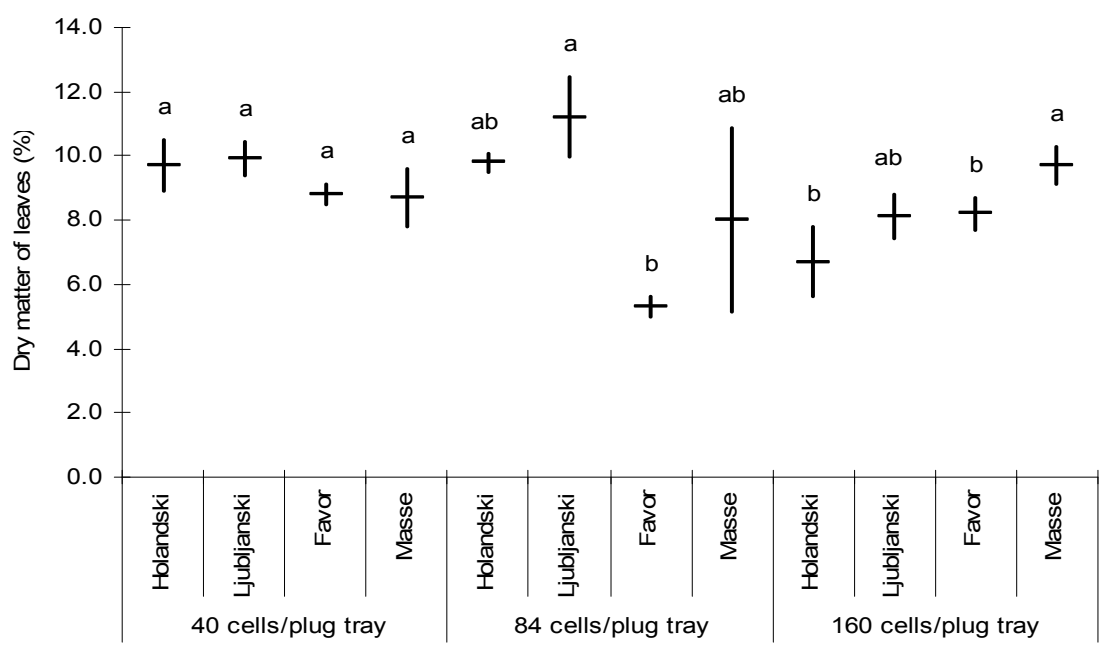

Figure 4: Influence of cell size on the percentage dry matter of leaves (\%). Vertical bars as in Fig. 1.

The dry matter content is the ratio between dry and fresh weight expressed as a percentage. According Raupp (2000) and Karić et al. (2005) percentage of dry matter of leaves is an important reference parameter, and is somewhat significant as well to a consumer who does not want to buy watery products. In our experiment, the cell size did no have significant and consistent effect on this parameter. In spite of this fact, there were tendencies for the dry matter content to decrease slightly as the cell volume was decreased. In other words, as plant population density increases, each plant produces less dry weight. The portion of dry matter decreased from 
$9.30 \%$ at $60 \mathrm{ml}$ cells ( 40 cells tray ${ }^{-1}$ ) to $8.20 \%$ at $20 \mathrm{ml}$ cells $\left(160\right.$ cells tray ${ }^{-1}$ ). These results are in agreement with those obtained by Žnidarčič et al. (2007) on cabbage. On the other hand, our results are not conformity with the findings of Agele at al. (1999) on tomato and Siomos (1999) on pak choi.

\section{CONCLUSIONS}

From the above results it can be concluded:

- $\quad$ all factors measured - plant height, leaf number and leaves fresh mass per plant - decreased as the cell volume decreased;

- $\quad$ restrictions in root growth reduces dry weight of leaves;

- most optimal plug tray for corn salad growing is 40 cells plug tray;

- cv. 'Holandski' (Semenarna) was considered as a suitable cultivar for growing in plug trays;

- last but no least, growing corn salads in plug trays has more advantages. For example, there are fewer weed problems, and the cropping time is shorter because of faster and better growth in artificial media. Furthermore, corn salad grown in plug trays need little or no chemical pesticide, this can be seen as a model of hygienic vegetable production

\section{LITERATURE}

Agele, S.O., Iremiren, G.O., Ojeniyi, S.O. 1999. Effects of plant density and mulching on the performance of late-season tomato (Lycopersicon esculentum) in southern Nigeria. J. Agr. Sci. Cambridge, 133: 397-402.

Csizinszky, A.A., Schuster, D.J. 1993. Impact of insecticide schedule, N and K rates, and transplant container size on cabbage yield. HortSci., 28: 299-301.

Karić, L., Vukašinović, S., Žnidarčič, D. 2005. Response of leek (Allium porrum L.) to different levels of nitrogen dose under agro-climate conditions of Bosnia and Herzegovina. Acta agric. Slov., 85, 2: 219-226.

Lee, W.S., Yang, S.R. 1999. Using a plug system to produce hygienic vegetables. (Sep. 1999), http://www.agnet.org/library/eb/477/ (15. Mar. 2008)

Liu, A., Latimer, J.G. 1995. Root cell volume in the planter flat affects watermelon seedling development and fruit yield. HortSci., 30: 242-246.

NeSmith, D.S. 1993. Summer squash response to root restriction under different light regimes. J. Plant Nutr., 16: 765-780.

NeSmith, D.S., Duval, J.R. 1998. The effect of container cell size. HortTech., 8, 4: 495-498.

Nicola, S. Cantliffe, D.J. 1996. Increasing cell size and reducing medium compression enhance lettuce transplant quality and field production. HortSci., 31, 2: 184-189.

Raupp, J. 2008. Fertilization effects on products quality and examination of parameters and methods for quality assessment. (Apr. 2000), http://www.edis.ifas.ufl.edu (06. Feb. 2008).

Sambo, P., Lunari, G., Gianquinto, G., Pimpini, F. 2001. Primi resultati di coltivazione dello spinaco (Spinaca oleraceae) in floating system. Italus Hortus, 8, 6: 64-69. 
Siomos, A.S. 1999. Planting date and within-row plant spacing effects on pak choi yield and quality characteristics. J. Veg. Crop Prod., 4, 2: 65-73.

Šink, P. 2006. Cultivation of rocket (Eruca sativa Mill.) and wild rocket (Diplotaxis tenuifolia L.) in plug trays. Grad. Thesis, University of Ljubljana, Biotechnical Faculty, Department of Agronomy, $45 \mathrm{p}$.

Walter, S.A., Riddle, A.A., Schmidr, M.E. 2005. Container cell volume and transplant age influences muskmelon development and yield. J. Veg. Sci., 11, 1: 47-55.

Vavrina, C.S., Olsen, S., Cornell, J.A. 1995. Watermelon transplant age: Influence on fruit yield. HortSci., 28: 789-790.

Vavrina, C.S. 2001. Bigger is actualy better: A study of transplant container size. (Nov. 2001), http://edis.ifas.ufl.edu (20. Feb. 2008).

Weston, L.A. 1988. Effect of flat cell size, transplant age, and production site on growth and yield of pepper transplants. HortSci., 23: 709-711.

van Iersel, M. 1997. Root restriction effects on growth and development of salvia (Salvia splendens F. Sellow ex Roem. \& Schult.). HortScience, 32: 1186-1190.

Weston, L.A., Zandstra, B.H. 1986. Effect of root container size and location of production on growth and yield of tomato transplants. J. Amer. Soc. Hort. Sci., 111: 498-501.

Žnidarčič, D., Kacjan-Maršić, N., Osvald, J., Požrl, T., Trdan, S. 2007. Yield and quality of early cabbage (Brassica oleracea L. var. capitata) in response to within-row plant spacing. Acta agric. Slov., 89, 1: 15-23. 